\title{
A brief review on natural fiber used as a replacement of synthetic fiber in polymer composites
}

\author{
Fatin I. Mahir ${ }^{1,2}$ Kamrun N. Keya ${ }^{1}$ Bijoyee Sarker ${ }^{1,2}$ Khandakar M. Nahiun ${ }^{1,2}$ Ruhul A. Khan ${ }^{1^{*}}$
}

\begin{abstract}
The use of composites in different sectors has become inevitable due to the enhancement in properties, reduction in the manufacturing cost and suitability to several applications. Among different classifications, polymeric composites are mainly focused on their use as structural components and the selection and composition of reinforcement play a vital role in determining the characteristics of the composite. Although composites are developed with man-made reinforcement in the beginning stage, in the present situation, natural reinforcements have proved excellent results in terms of properties. Hence, nowadays researches are mainly focused on the use of different natural fibers in different forms as reinforcements in polymeric composite. This work presents a brief overview on the properties of natural fiber and natural fiber reinforced composites which is an emerging area in polymer science. Interests in natural fiber is reasonable due to the advantages of these materials compared to others, such as synthetic fiber composites, including low environmental impact and low cost and support their potential to be used. Moreover, the disadvantage of the synthetic and fiber-glass as reinforcement, the use of natural fiber reinforced composite gained the attention of the young scientists, researchers, and engineers and are being exploited as a replacement for the conventional fiber such as glass, aramid, carbon etc. Natural fibers have been proven alternative to synthetic fiber in transportation such as automobiles, railway coaches and aerospace, military, building, packaging, consumer products and construction industries for ceiling paneling, partition boards etc. However, in development of these composites, some drawbacks have also emerged. In this paper, it has been tried to overview all of this together.
\end{abstract}

Keywords: natural fiber, synthetic fiber, polymer composite, composite and bio-degradable

\section{Introduction}

Fiber reinforced polymer materials are composites which possess high strength fibers (reinforcement) embedded in polymeric matrices. Fibers in these materials are the load-carrying elements and provide strength and rigidity, while the polymer matrices uphold the alignment of the fibers (position and orientation). They also protect them against the environment and other possible damages. A pure polymer does not usually have the required mechanical strength for application in various fields. The reinforcement by high strength fibers provides the polymer substantially enhanced mechani-

\footnotetext{
Received: June 18, 2019 Accepted: July 9, 2019 Published: July 17, 2019

* Correspondence to: Ruhul A. Khan, Institute of Radiation and Polymer Technology, Bangladesh Atomic Energy Commission, Dhaka 1349, Bangladesh; Email: nology, Bangladesh Atom
dr.ruhul_khan@yahoo.com

${ }^{1}$ Institute of Radiation and Polymer Technology, Bangladesh Atomic Energy Commission, Dhaka 1349, Bangladesh

${ }^{2}$ National Institute of Textile Engineering and Research, Nayarhat, Savar, Dhaka 1350, Bangladesh

Citation: Mahir FI, Keya KN, Sarker B, et al. A brief review on natural fiber used as a replacement of synthetic fiber in polymer composites. Mater Eng Res, 2019, 1(2): 86-97.

Copyright: (c) 2019 Ruhul A. Khan, et al. This is an open access article distributed under the terms of the Creative Commons Attribution License, which permits unrestricted use, distribution, and reproduction in any medium, provided the original author and source are credited.
}

cal properties which make the fiber reinforced polymer composites suitable for a large number of miscellaneous applications. The fiber reinforced polymer composites are developed primarily using synthetic fibers such as glass, carbon, aramid, Kevlar, etc. But the growth in environmental consciousness, community interest, the new environmental regulations and unsustainable consumption of man-made materials, led to thinking of the use of environmentally friendly materials. Owing that view natural fiber is considered as one of the best environmentally friendly materials which have good properties compared to synthetic fiber. ${ }^{[1]}$ Because of that in the recent decades, natural fibers as an alternative of synthetic fibers in the reinforcement of polymer composites have attracted the attention of many researchers and scientists due to their advantages over conventional glass and carbon fibers and others. Among these natural fibers, flax, hemp, jute, sisal, kenaf, coir, kapok, banana, henequen, and many others are very much recognized now. The application of natural fiber polymer composites has expanded noticeably in the shopper merchandise as developing industry sectors throughout the last few years. Its applications are growing rapidly in several engineering 
fields. The different kinds of natural fibers reinforced polymer composite have received a great importance in different automotive applications by many automotive companies including Cambridge industry (an auto industry in the USA), Proton company (Malaysian national carmaker) and German auto companies (BMW, Audi Group, Ford, Opel, Volkswagen, Daimler Chrysler, and Mercedes). Besides the auto industry, the applications of natural fiber composites have also been found in the civil industry, sports, aerospace, and others, for example, panels, window frame, decking, and bicycle frame. ${ }^{[2]}$

Recent researches found that the worldwide natural fiber reinforced polymer composites industry sector reached U\$2.1 billion in 2010. As indicated by evaluations, over 5 years (2011-2016), the natural fiber polymer composites industry is estimated to grow $10 \%$ worldwide. So, without a second thought, it can be said that the field of natural fiber composite will grow more rather than the synthetic fiber composite in the upcoming future. ${ }^{[3]}$

\section{Composite}

The term 'composite' in material science refers to a material made up of a medium containing reinforcing agents. Reinforcement can be described as the part of the composite that offers strength, stiffness, and the ability to carry a load. The most largely used meaning is the following one, which has been stated by Jartiz "Composites are multifunctional material systems that provide characteristics not obtainable from any discrete material. They are cohesive structures made by physically combining two or more compatible materials, different in composition and characteristics and sometimes in form". According to the scientist Kelly the composites should not be regarded as simple as a combination of two materials. Beghezan defines as "The composites are compound materials which differ from alloys by the fact that the individual components retain their characteristics but are so incorporated into the composite as to take advantage only of their attributes and not of their short comings." If the definition is described in simpler way then it can be said that a composite material (also called composite, which is the common name) is a material made from two or more basic materials with significantly different physical or chemical properties that, when combined, produce a material with characteristics different from the individual. ${ }^{[4]}$

If examples are provided then wood can be said as a natural composite of cellulose fibers in a matrix of lignin. Generally, mud, cement, polymers, metals and ceramics are used in the matrix. The most common polymer-based composite materials include fiberglass, carbon fiber and Kevlar. Generally, polymer can be classified into two classes, thermoplastics and thermosetting. Thermoplastic materials currently dominate, as matrices for biofibers; the most commonly used thermoplastics for this purpose are polypropylene (PP), polyethylene, and poly vinyl chloride (PVC); while phenolic, epoxy and polyester resins are the most commonly used thermosetting matrices. The beginning of composite materials can't be predicted properly. But it may have been the bricks fashioned by the ancient Egyptians from mud and straw. The ancient brick-making procedure can still be seen on Egyptian tomb paintings in the Metropolitan Museum of Art. Commercialization of the composites could be traced to early century when the cellulose fibers were used to reinforce phenolics, urea and melamine resins. ${ }^{[5]}$

\section{Types of composites}

In a simpler way, composites can be classified based on the nature of the matrix each type possesses. Fabrication method also varies according to the physical and chemical properties of the matrices and reinforcing fibers. ${ }^{[6]}$

\subsection{Polymer matrix composites}

This type is the most common and advanced composites. These are made of a polymer thermoplastic or thermosetting reinforced by fiber (natural carbon or boron). These materials can be shaped into different shapes and sizes. They offer great strength and stiffness along with resistance to corrosion. The purpose of these being most public is their low cost, high strength, and simple manufacturing principles.

\subsection{Metal matrix composites}

This composite has a metal matrix. Aluminum, magnesium, titanium can be called the example of this composite's matrices. The typical fiber includes silicon carbide and carbon. Metals are mainly reinforced to suit the needs of the design.

\subsection{Ceramic matrix composites}

Ceramic matrix composites have ceramic matrix such as alumina, calcium, aluminosilicate which are reinforced by silicon carbide. High strength, hardness, high service temperature limits for ceramics, chemical inertness and low density can be achieved in this matrix. Composites effectively made with ceramic matrices are reinforced with silicon carbide fibers and these composites offer the same high-temperature tolerance of super- 
alloys without such a high density. The brittle nature of ceramics makes composite fabrication difficult. Usually, most CMC production procedures involve preliminary materials in powder form.

\subsection{Carbon-Carbon composites}

CCMs use carbon fibers in a carbon matrix. Carboncarbon composites are used in very high-temperature environments of up to $60000 \mathrm{~F}$ and are twenty times stronger and thirty times lighter than graphite fibers.

\section{Facts of composite}

\subsection{Light weight}

Composites are light in weight, compared to most woods and metals. This property can be used in automobiles and aircraft, because less weight means better fuel efficiency. During the design of airplanes, weight of the airplane is always kept in mind because reduced weight increases the speed. Boeing 787, Dreamliner is an example of modern technology.

\subsection{High strength}

Composites can be designed to be far tougher than aluminum or steel. Though metals are strong in various directions, composites can be planned and designed to be strong in a precise direction.

\subsection{Strength related to weight}

Strength-to-weight ratio is a material's strength in relation to how much it weighs. Some materials are very strong and heavy, such as steel. This property is to build airplanes - which need a very high strength material having lowest possible weight. Composites can be strong without being heavy. Now a days composites have the highest strength-to-weight ratios in structures.

\subsection{Corrosion resistance}

Composites have a great abundance against the weather and from harsh chemicals that can damage other materials. Composites are good choices where chemicals are handled or stored.

\subsection{High-Impact strength}

Composites can be made to captivate impacts-the sudden force of a bullet, for instance, or the blast from an explosion. Because of this reason, composites are applied in bulletproof vests and panels, and to shield airplanes, buildings, and military vehicles from explosions.

\subsection{Design flexibility}

Composites can be molded into complicated shapes more easily than most other materials. This gives designers the freedom to create almost any shape or form. Most recreational boats today, for example, are built from fiberglass composites because these materials can easily be molded into complex shapes, which improve boat design while lowering costs. The surface of composites can also be molded to mimic any surface finish or texture, from smooth to pebbly.

\subsection{Part consolidation}

A single piece made of composite materials can replace an entire assembly of metal parts. Reducing the number of parts in a machine or a structure saves time and cuts down on the maintenance needed over the life of the item.

\subsection{Dimensional stability}

Composites retain their shape and size when they are hot or cool, wet or dry. Wood, on the other hand, swells and shrinks as the humidity changes. They are used in aircraft wings for example.

\subsection{Nonconductive}

Composites are nonconductive, meaning they do not conduct electricity. Because of this reason they are suitable for such items as electrical utility poles and the circuit boards in electronics. But if electrical conductivity is needed for any reason, it is possible to make some composites conductive.

\subsection{Radar transparent}

Radar signals pass right through composites, a property that makes composites ideal materials for use anywhere radar equipment is operating, whether on the ground or in the air. Composites play a crucial role in stealth aircraft, such as the U.S. Air Force's B-2 stealth bomber, which is nearly invisible to radar.

\subsection{Low thermal conductivity}

Composites are decent insulators-they do not simply conduct heat or cold. They can be used in buildings for doors, panels, and windows where further protection is required from severe weather.

\subsection{Durable}

Structures made of composites have an extended life and need slight maintenance. It can be said that how long composites last, because many original composites 
have not come to the last point. Many composites have been in service for half a century. ${ }^{[4,7]}$

\section{Natural fiber and its classification}

In a simpler way fiber that is not synthetic or manmade can be called natural fiber. They can be sourced from plants or animals. Natural fiber can be classified according to their origin as:

\subsection{Animal fibers}

It contains wool, silk, avian fiber. It includes sheep's wool, goat hair, horse hair, feathers, and feathers fiber,etc.

\subsection{Mineral fiber}

Mineral fibers are naturally occurring fiber and they are slightly modified fiber procured from minerals. These can be further characterized as asbestos, Ceramic, Metal Fiber.

\subsection{Plant fiber}

Plant fibers are generally comprised mainly of cellulose. This fiber can be further categorizing into the following:

(1) Seed Fiber: Fibers which are collected from the seed and seed case, e.g. cotton and kapok.

(2) Leaf Fiber: Fibers collected from the leaves, e.g. sisal and agave.

(3) Skin Fiber: Fibers are collected from the skin or bast surrounding the stem of their respective plant. These fibers consume higher tensile strength than remaining fibers. Therefore, these fibers are used for durable yarn, fabric, packaging, and paper. Flax, jute, banana, hemp, and soybean can be said as an example.

(4) Fruit Fiber: These fibers are collected from the fruit of the plant, e.g. coconut (coir) fiber.

(5) Stalk Fiber: Fibers are actually the stalks of the plants such as straws of wheat, rice, barley, and other crops including bamboo and grass. Tree wood is also such a fiber. ${ }^{[7]}$

\section{Chemical composition of natural fiber}

The organic composition of natural fibers differs reliant upon the type of fiber. Mainly, fibers contain cellulose, hemicellulose, pectin, wax, and lignin. The properties of each component contribute to the overall properties of the fiber. Hemicellulose is in charge of the biodegradation, moisture absorption, and thermal dilapidation of the fiber as it shows the least resistance whereas lignin is thermally constant but is responsible for the
UV degradation. The percentage composition of each of these components varies for unlike fibers. Generally, the fibers contain $60-80 \%$ cellulose, 5-20\% lignin, and up to $20 \%$ moisture. $^{[8-10]}$

\section{Prior studies on natural fiber reinforced composite}

Obtaining a standard strength is the first target of a composite which has been done in many composites by using different types of natural fiber. Ferreria et al. ${ }^{[11]}$ improved the fatigue strength by using hybrid fiber composites with a polypropylene hemp layer next to the bond interface which was expected to produce more uniform stress in transient regions. Eucalyptus urograndis pulp used as the reinforcement for thermoplastic starch showed an increase of $100 \%$ in tensile strength and more than $50 \%$ in modulus with respect to non-reinforced thermoplastic starch. ${ }^{[12]}$

Fiber reinforced composite materials offered a combination of strength and modulus that are either similar to or better than many old-style metallic materials. The rise in the flax and jute fiber content in polyurethane based composites increased the shear modulus and impact strength. However, increasing the microvoid content in the matrix decreased its strength. ${ }^{[13]}$

Jayaraman and Bhattacharya ${ }^{[14]}$ reported the mechanical performance of wood fiber waste based plastic composites and observed that tensile strength does not generally change with fiber content. Zulkifli et al. ${ }^{[15]}$ prepared Natural Rubber (NR)- Polypropylene (PP) composites by increasing the amount of NR in PP hemp mat reinforced phenolic composites. Eucalyptus urograndis pulp used as the reinforcement for thermoplastic starch showed an increase of $100 \%$ in tensile strength and more than $50 \%$ in modulus with respect to non-reinforced thermoplastic starch. ${ }^{[12]}$

Fiber reinforced composite materials offered a mixture of strength and modulus which are either comparable to or better than many traditional metallic materials. Growth in the flax and jute fiber content in polyurethane based composites has resulted in the rise of the shear modulus and impact strength. However, increasing the microvoid content in the matrix decreased its strength. ${ }^{[13]}$ Jayaraman and Bhattacharya ${ }^{[14]}$ reported the mechanical performance of wood fiber waste based plastic composites and observed that tensile strength does not generally change with fiber content. Zulkifli et al. ${ }^{[15]}$ prepared Natural Rubber (NR)- Polypropylene (PP) composites by increasing the amount of NR in PP. Mitra et al. ${ }^{[16]}$ treated the unwoven jute fiber with pre-condensate like formaldehyde, melamine formaldehyde and polymerized 
Table 1. Chemical composition of different natural fibers

\begin{tabular}{|c|c|c|c|c|}
\hline Fiber & $\begin{array}{c}\text { Cellulose } \\
(\mathrm{wt} \%)\end{array}$ & $\begin{array}{l}\text { Hemicellulose } \\
(\mathrm{wt} \%)\end{array}$ & $\begin{array}{l}\text { Lignin } \\
(w t \%)\end{array}$ & $\begin{array}{c}\text { Wax } \\
\left(w^{0} \%\right)\end{array}$ \\
\hline Bagasse & 55.2 & 16.8 & 25.3 & ---- \\
\hline Bamboo & $26-43$ & 30 & $21-31$ & ---- \\
\hline Flax & 71 & $18.6-20.6$ & 2.2 & 1.5 \\
\hline Kenaf & 72 & 20.3 & 9 & ---- \\
\hline Jute & $61-71$ & $14-20$ & $12-13$ & 0.5 \\
\hline Cotton & 82.7 & 5.7 & ---- & ---- \\
\hline Hemp & 68 & 15 & 10 & 0.8 \\
\hline Ramie & $68.6-76.2$ & $13-16$ & $0.6-0.7$ & 0.3 \\
\hline Abaca & $56-63$ & $20-25$ & $7-9$ & 3 \\
\hline Sisal & 65 & 12 & 9.9 & 2 \\
\hline Coir & $32-43$ & $0.15-0.25$ & $40-45$ & ---- \\
\hline Oil Palm & 65 & ---- & 29 & ---- \\
\hline Pineapple & 81 & ---- & 12.7 & --- \\
\hline Curaua & 73.6 & 9.9 & 7.5 & ---- \\
\hline Wheat Straw & $38-45$ & $15-31$ & $12-20$ & ---- \\
\hline Rice husk & $35-45$ & $19-25$ & 20 & ---- \\
\hline Rice straw & $41-57$ & 33 & $8-19$ & $8-38$ \\
\hline Althaea & 44.6 & 13.5 & 2.7 & ---- \\
\hline Acacia planifrons (Umbrella thorn) & 73.1 & 9.41 & 12.04 & 0.57 \\
\hline Prosopis juliflora & 61.65 & 16.14 & 17.11 & 0.61 \\
\hline Acacia leucophloea & 68.09 & 13.60 & 17.73 & 0.55 \\
\hline Tarmarind & 59 & 22 & 19 & ---- \\
\hline Ferula & 53.3 & 8.5 & 2.7 & ---- \\
\hline Acacia arabica & 68.10 & 9.36 & 16.86 & 0.49 \\
\hline Sansevieria cylindrica & 79.7 & 10.13 & 3.8 & 0.09 \\
\hline Cyperus pangorei & 68.5 & ---- & 17.88 & 0.17 \\
\hline Sponge gourd & 62 & 20 & 13 & ---- \\
\hline Grewia tilifolia & 62.80 & 21.20 & 14.90 & \\
\hline Oil palm empty fruit bunch & 65 & 29 & 17.5 & 4 \\
\hline Henequen & 60 & 28 & 8 & 0.5 \\
\hline Agave & 68.42 & 4.85 & 4.85 & 0.26 \\
\hline Sansevieria ehrenbergii & 80 & 11.25 & 7.8 & 0.45 \\
\hline Wood & 48 & 15 & 24 & ---- \\
\hline Borassus & 53.40 & 29.6 & 29.6 & ---- \\
\hline Banana & $60-65$ & $6-8$ & $5-10$ & ---- \\
\hline Cissus quadrangularis & 77.17 & 11.02 & 10.45 & 0.14 \\
\hline Palmyrah & $40-52$ & $42-43$ & ---- & ---- \\
\hline Hop stem & 84 & ---- & 6 & ---- \\
\hline Okra & $60-70$ & $15-20$ & $5-10$ & 3.9 \\
\hline Ipomoea staphylina & 72.261 & 13.6 & 19.56 & 1.51 \\
\hline Nettle & $53-86$ & $4-103$ & $3.5-9.4$ & $3.1-4.2$ \\
\hline Straw & 76 & 15 & 1 & ---- \\
\hline Ficus & 38.1 & 30.5 & 23.4 & ---- \\
\hline Thespesia lampas & 60.63 & 26.64 & 12.70 & ---- \\
\hline Century plant & 71.65 & 22.24 & 6.09 & ---- \\
\hline Mending grass & 72.14 & 20.2 & 3.44 & ---- \\
\hline Napier grass strands & 47.123 & 31.27 & 21.63 & ---- \\
\hline Isora & 74 & & 23 & 1.09 \\
\hline Kudzu & 33 & 11.6 & 14 & ---- \\
\hline Sun hemp & $41-48$ & $8.3-13$ & 22.7 & ---- \\
\hline Piassava & 28.6 & 25.8 & 45 & ---- \\
\hline Rhectophyllum camerunense & 68.2 & 16 & 15.6 & ---- \\
\hline Linen & 82 & 2 & 4 & ---- \\
\hline Kapok & 13 & ---- & & ---- \\
\hline Henequen & 77.6 & 13.1 & $4-8$ & ---- \\
\hline Olive husk & $24-36$ & $22-27$ & $26-48.4$ & ---- \\
\hline Almond husk & 14 & 14 & 13 & ---- \\
\hline Areca Husk & 0 & $35-65$ & $13-25$ & ---- \\
\hline Sun flower hull & $38.1-39.5$ & $16.5-17.1$ & $23.7-24.7$ & ---- \\
\hline
\end{tabular}

Materials Engineering Research (C) 2019 by Syncsci Publishing. All rights reserved. 
cashew nut shell liquid formaldehyde, past to its use as reinforcing material for the preparation of composites. The treatment reduced the moisture absorbance of the jute.

Kandola et al. ${ }^{[17]}$ described the fabrication of novel glass reinforced epoxy composites containing phosphate. Eichhorn and Young ${ }^{[18]}$ studied the deformation in micromechanics of natural cellulose fiber networks and composites. Kaith et al., ${ }^{[19]}$ Singha AS et al. ${ }^{[20]}$ prepared polymer matrix-based composites using flax-gcopolymers, flax fiber, and mercerized flax as a reinforcing agent. It was detected that the reinforcement increased the endurance of the composite to higher loads as compared to pure polystyrene. ${ }^{[21]}$

Table 2. Equilibrium estimated content of different natural fiber

\begin{tabular}{cc}
\hline Fiber & Amount of Production (ton) \\
\hline Bamboo & 30000 \\
Wool & 1.2 million \\
Cotton & 26 million \\
Sugar cane Bagasse & 75000 \\
Jute & 3.3 million \\
Kenaf & 3 million \\
Flax & 200,000 \\
Grass & 700 \\
Sisal & 375 \\
Hemp & 7500 \\
Coir & 100 \\
Ramie & 100 \\
Abaca & 70 \\
Silk & 200,000 \\
\hline
\end{tabular}

Table 3. Equilibrium moisture content of different natural fiber

\begin{tabular}{cc}
\hline Fiber & Equilibrium Moisture Content (\%) \\
\hline Hemp & 11 \\
Jute & 9 \\
Flax & 12 \\
Abaca & 7 \\
Ramie & 15 \\
Pineapple & 9 \\
Coir & 13 \\
Bagasse & 10 \\
Bamboo & 8.8 \\
Sisal & 8.9 \\
\hline
\end{tabular}

\section{Mechanical properties}

The Fiber reinforced polymer composites are developed primarily using synthetic fibers such as glass, carbon, aramid, Kevlar, etc. Synthetic fiber reinforced polymer composites have unique advantages over monolithic polymer materials. As well as high strength and high stiffness, these composites have long fatigue life and adaptability to the intended function of the structure. Although the synthetic fiber reinforced polymer composites possess exclusive mechanical strength, they have got some serious drawbacks such as high cost, high density (as compared to polymers), and poor recycling and nonbiodegradable properties. For these reasons, over the last few years natural plant fibers reinforced polymer composites are increasingly gaining attention as a viable alternative to synthetic fiber reinforced polymer composites. $^{[22,23]}$ The mechanical properties and physical properties of natural fibers differ significantly and it depends mostly on the chemical and structural composition, fiber type and growth conditions. If the natural fibers are considered individually, they may not provide a very satisfactory result but in the case of reinforcing their performance is very much significant.

\section{Advantages of natural fiber}

(1) Low cost and high performance of NFRPCs contented the economic feature of the industry.

(2) The dumping of NFRPCs is simple as compared to SFRPCs.

(3) The abrasive nature of fiber is much minor which leads to advantages in regard to practical process and recycling process of the composite materials.

(4) Natural fiber composites are used in place of glass which are mainly in nonstructural applications. Different automotive components such as doors, bonnets, etc. made from glass fiber reinforced composites are now being replaced by natural fiber reinforced composites.

(5) Good thermal and acoustic insulating properties.

(6) Low specific weight results in higher strength and stiffness than glass.

(7) Renewable resources and production require less energy.

(8) The most important thing is these are bio degradable. ${ }^{[6,7]}$

\section{Disadvantages of using natural fiber}

Even though natural fibers are obtained from renewable sources and the polymer composites based on them are ecologically friendly as compared to the synthetic fiber reinforced composites, there are also some drawbacks, which are related to the exploitation of basic/raw fibers in the preparation of the composites.

(1) High moisture uptake is the major drawback of the natural fibers. This phenomenon weakens the interfacial bonding between the polymer matrix and fiber and causes deterioration of the mechanical properties. 
Table 4. Improvements of the mechanical properties of some epoxy-based polymer composites

\begin{tabular}{|c|c|c|c|c|c|c|}
\hline Resin & $\begin{array}{l}\text { Reinforcing } \\
\text { Fibers }\end{array}$ & $\begin{array}{l}\text { Investigated } \\
\text { mechanical } \\
\text { Properties }\end{array}$ & $\begin{array}{l}\text { Properties of the } \\
\text { base polymer } \\
(\mathrm{MPa})\end{array}$ & $\begin{array}{c}\text { Property } \\
\text { Improvement } \\
\%\end{array}$ & $\begin{array}{c}\text { Corresponding } \\
\text { Fiber content } \\
\%\end{array}$ & References \\
\hline & Banana & & 23.98 & 90 & - & {$[24]$} \\
\hline \multirow[t]{9}{*}{ Epoxy } & Coconut & Tensile strength & ----- & & $30 \mathrm{w}$ & {$[25]$} \\
\hline & & & & 307.82 & & \\
\hline & Banana & & 53.38 & 38 & - & [24] \\
\hline & Bagasse & Flexural strength & - & 23.34 & $30 \mathrm{w}$ & [26] \\
\hline & Coconut & & - & 39.4 & $30 \mathrm{w}$ & {$[25]$} \\
\hline & Pine apple leaf & $\begin{array}{l}\text { Interfacial shear } \\
\text { strength (IFSS) }\end{array}$ & - & 152 & - & [27] \\
\hline & Banana & Young's & 1390 & 36 & - & [24] \\
\hline & Coconut & modulus & - & 54.89 & $30 \mathrm{w}-$ & [25] \\
\hline & Banana & Flexural modulus & 1563.2 & 17.37 & - & [24] \\
\hline
\end{tabular}

Table 5. Improvements of the mechanical properties of some polyethylene-based composites

\begin{tabular}{|c|c|c|c|c|c|c|}
\hline Resin & $\begin{array}{l}\text { Reinforcing } \\
\text { Fibers }\end{array}$ & $\begin{array}{l}\text { Investigated } \\
\text { mechanical } \\
\text { Properties }\end{array}$ & $\begin{array}{l}\text { Properties of the } \\
\text { base polymer } \\
(\mathrm{MPa})\end{array}$ & $\begin{array}{c}\text { Property } \\
\text { Improvement } \\
\%\end{array}$ & $\begin{array}{c}\text { Corresponding } \\
\text { Fiber content } \\
\%\end{array}$ & References \\
\hline & Jute & & 250 & 900 & $60 \mathrm{v}$ & {$[28]$} \\
\hline & Pine apple- leaf & & 22.9 & & $30 \mathrm{w}$ & [29] \\
\hline & Okra & & & & & \\
\hline \multirow[t]{4}{*}{ Polyester } & Coir & Tensile strength & 28 & 176 & $27.61 \mathrm{v}$ & {$[30]$} \\
\hline & Bagasse & & - & 135 & $25 \mathrm{w}$ & [31] \\
\hline & & & 10.6 & 30 & $65 \mathrm{w}$ & {$[32]$} \\
\hline & & & & 152 & & \\
\hline \multirow[t]{3}{*}{ Polyester } & Pine apple- leaf & & 80.2 & 38 & $30 \mathrm{w}$ & [29] \\
\hline & Coir & & & 23.34 & & \\
\hline & Bagasse & Flexural strength & - & 39.4 & $25 \mathrm{w}$ & [31] \\
\hline \multirow[t]{2}{*}{ Vinyl Ester } & Hemp & & - & & $65 \mathrm{w}$ & {$[32]$} \\
\hline & & & - & & $20 \mathrm{w}$ & {$[33]$} \\
\hline \multirow[t]{4}{*}{ Polyester } & Jute & Young's & 4000 & & $60 \mathrm{w}$ & {$[28]$} \\
\hline & Pine apple- leaf & modulus & 580 & & $40 \mathrm{w}$ & [29] \\
\hline & Okra & & & 152 & & \\
\hline & Hemp & & 525 & & $37.5 \mathrm{w}$ & {$[30]$} \\
\hline Vinyl Ester & & & - & & $20 \mathrm{w}$ & {$[33]$} \\
\hline Polyester & Pine apple leaf & & 1300 & 36 & $30 \mathrm{w}$ & [29] \\
\hline \multirow[t]{2}{*}{ Vinyl Ester } & Hemp & Flexural modulus & & & & \\
\hline & & & - & 54.89 & $20 \mathrm{w}$ & {$[33]$} \\
\hline
\end{tabular}

Note: $v=$ Fiber Content in volume $\%$; $w=$ Fiber content in weight $\%$ 
Table 6. Improvements of the mechanical properties of some polyester-based composites

\begin{tabular}{|c|c|c|c|c|c|c|}
\hline Resin & $\begin{array}{c}\text { Reinforcing } \\
\text { Fibers }\end{array}$ & $\begin{array}{c}\text { Investigated } \\
\text { mechanical } \\
\text { Properties }\end{array}$ & $\begin{array}{c}\text { Properties of the } \\
\text { base polymer } \\
(\mathrm{MPa})\end{array}$ & $\begin{array}{c}\text { Property } \\
\text { Improvement } \\
\% \\
\end{array}$ & $\begin{array}{c}\text { Corresponding } \\
\text { Fiber content } \\
\% \\
\end{array}$ & References \\
\hline \multirow{3}{*}{ LDPE } & Sisal (treated) & & 9.2 & 60 & $30 \mathrm{w}$ & [34] \\
\hline & Sisal & Tensile Strength & 9 & 245 & $21.5 \mathrm{v}$ & {$[35]$} \\
\hline & Wood(treated) & & 9.8 & 67 & $40 \mathrm{w}$ & {$[36]$} \\
\hline \multirow{3}{*}{ LDPE } & Sisal(untreated) & Young's & 140 & 458 & $30 \mathrm{w}$ & {$[34]$} \\
\hline & Sisal(untreated) & modulus & 140 & 853 & $21.5 \mathrm{v}$ & {$[35]$} \\
\hline & Wood & & 350 & 272 & $40 \mathrm{w}$ & {$[36]$} \\
\hline \multirow{4}{*}{ HDPE } & Hemp & & \multirow{4}{*}{1070} & 555 & $60 \mathrm{w}$ & \multirow{4}{*}[37]{} \\
\hline & Rice hulls & & & 181 & $60 \mathrm{w}$ & \\
\hline & Hardwood A & & & 349 & $60 \mathrm{w}$ & \\
\hline & Hardwood B & & & 349 & $60 \mathrm{w}$ & \\
\hline
\end{tabular}

Note: $L D P E=$ Low Density Polyethylene HDPE $=$ High Density Polyethylene

$\mathrm{v}=$ Fiber Content in volume $\%$; $\mathrm{w}=$ Fiber content in weight $\%$

Table 7. Improvements of the mechanical properties of some PP-based composites

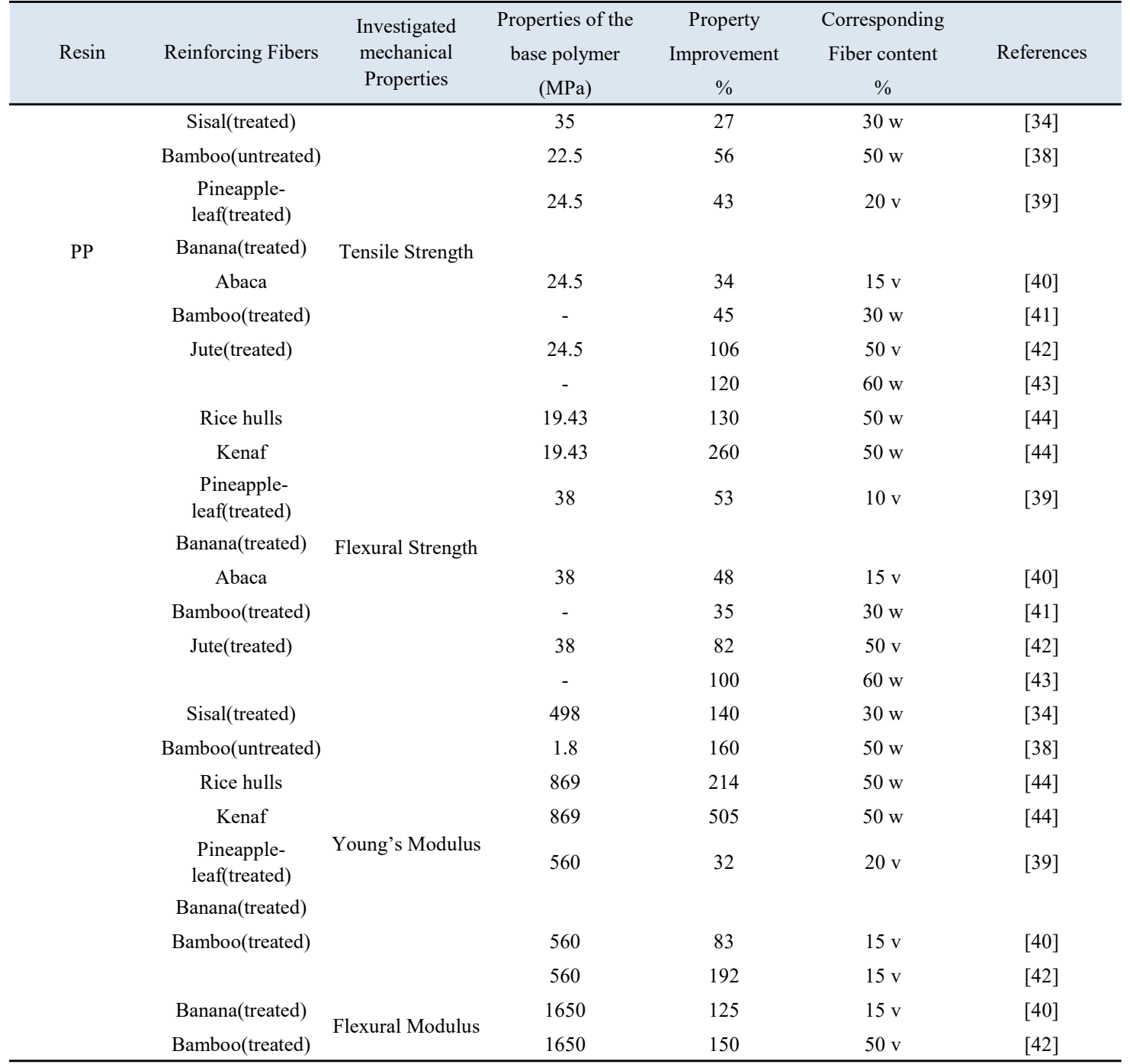

Note: $v=$ Fiber Content in volume $\%$; $w=$ Fiber content in weight $\%$ 
Table 8. Mechanical properties of some natural and synthetic fibers ${ }^{[8,10,45-47]}$

\begin{tabular}{|c|c|c|c|c|}
\hline Fiber & Tensile Strength (MPa) & Young's Modulus (GPa) & Density (g/cm3) & Elongation at break \% \\
\hline OPEFB & 248 & 3.2 & $0.7-1.55$ & 2.5 \\
\hline Flax & $88-1500$ & $60-80$ & 1.4 & $1.2-1.6$ \\
\hline Hemp & $550-900$ & 70 & 1.48 & 1.6 \\
\hline Wool & $120-174$ & $2 .-3.4$ & & $25-35$ \\
\hline Linen & 800 & $50-70$ & 1.4 & $2.7-3.5$ \\
\hline Jute & $400-800$ & $10-30$ & 1.46 & 1.8 \\
\hline Ramie & 500 & 44 & 1.5 & 2 \\
\hline Coir & 220 & 6 & 1.25 & $15-25$ \\
\hline Sisal & $600-700$ & 38 & 1.33 & $2-3$ \\
\hline Abaca & 980 & - & 1.5 & - \\
\hline Cotton & 400 & 12 & 1.51 & $3-10$ \\
\hline Kenaf (bust) & 295 & - & 1.2 & $2.7-6.9$ \\
\hline Kenaf (core) & - & - & 0.21 & - \\
\hline Bagasse & $20-290$ & $19.7-27.1$ & 1.2 & 1.1 \\
\hline Henequen & $430-580$ & - & 1.4 & $3-4.7$ \\
\hline Pine apple & $170-1672$ & 82 & 1.5 & $1-3$ \\
\hline Banana & 355 & 33.8 & 1.35 & 53 \\
\hline Coconut & $131-175$ & $4-13$ & 0.8 & $15-40$ \\
\hline Softwood Craft Pulp & 1000 & 40 & 1.5 & 4.4 \\
\hline E-Glass & $2000-3500$ & 70 & 2.5 & 0.5 \\
\hline S-glass & 4570 & 86 & 2.5 & 2.8 \\
\hline Aramid & $3000-3150$ & $63-67$ & 1.4 & $3.3-3.7$ \\
\hline Carbon & 4000 & $230-240$ & 1.4 & $1.4-1.8$ \\
\hline Borassus & 65.2 & 4.918 & & 47.2 \\
\hline Acacia leucophloea & $317-1608$ & $8.41-69.61$ & 1.385 & $1.38-4.24$ \\
\hline Piassava & $134.58-142.9$ & $1.07-4.59$ & & $6.4-21.9$ \\
\hline Curaua & $1250-3000$ & $30-80$ & & $4.5-6$ \\
\hline Bamboo & 503 & 35.91 & $0.6-1.1$ & 1.4 \\
\hline Palmyrah & $180-215$ & $7-604$ & 1.2 & $7-15$ \\
\hline Date palm & $97-196$ & $2.5-5.4$ & 0.92 & $2-4.5$ \\
\hline Isora & $500-600$ & & $1.2-1.3$ & $5-6$ \\
\hline Nettle & 650 & 38 & & 1.7 \\
\hline Kudzu & $130-418$ & & & \\
\hline Okra & $68-282$ & $5.74-16.55$ & & 2 \\
\hline Oil palm & $100-400$ & $1-9$ & $0.7-1.55$ & $8-18$ \\
\hline
\end{tabular}


(2) Limited maximum processing temperature.

(3) Natural fiber reinforced polymer composites don't give good result in case of fire. They do have poor fire resistance properties which is not really beneficiary.

(4) Prices may fluctuate according to harvest results or agricultural politics. Sometimes this could result in less using of natural fiber or it can hamper the supply of natural during requirement.

\section{Natural fiber composite application}

Hemp fiber: This fiber is used in various fields of modern time. Construction products, textiles, cordage, geotextiles, paper \& packaging, furniture, electrical, manufacture banknotes, and manufacture of pipes are the mostly used sectors of hemp fiber.

Oil palm fiber: This fiber is much useful for building materials such as windows, door frames, structural insulated panel building systems, siding, fencing, roofing, decking, and other building materials.

Wood fiber: This fiber is mainly used in the basic structural component. Window frame, panels, door shutters, decking, railing systems, and fencing can be an example of it.

Flax fiber: Window frame, panels, decking, railing systems, fencing, tennis racket, bicycle frame, fork, seat post, snowboarding, and laptop cases.

Rice husk fiber: Being a little bit cheap this fiber is fulfilling the requirement very effectively. Building materials such as building panels, bricks, window frame, panels, decking, railing systems, and fencing are the sectors of this fiber.

Bagasse fiber: This fiber has become very much useful and popular nowadays. The wide application is being tried to be done to make this fiber more widespread. Window frame, panels, decking, railing systems, and fencing.

Sisal fiber: In construction industries such as panels, doors, shutting plate, and roofing sheets; also, manufacturing of paper and pulp this fiber is used in vast amount.

Stalk fiber: Building panel, furniture panels, bricks, and constructing drains and pipelines are the reservation section of this fiber.

Kenaf fiber: Packing material, mobile cases, bags, insulations, clothing-grade cloth, soilless potting mixes, animal bedding, and material that absorbs oil and liquids.

Cotton fiber: This fiber is the most explored fiber in the world. The application of this fiber is beyond description. It fulfills the required desire in various sections of science. They are basically used in the furniture industry, textile and yarn, goods, and cordage.

Coir fiber: Building panels, flush door shutters, roof- ing sheets, storage tank, packing material, helmets and post boxes, mirror casing, paperweights, projector cover, voltage stabilizer cover, a filling material for the seat upholstery, brushes and brooms, ropes and yarns for nets, bags, and mats, as well as padding for mattresses, seat cushions are the main applied section for this fiber.

Ramie fiber: This fiber is very much useful in textile purpose. They are being used in products as industrial sewing thread, packing materials, fishing nets, and filter cloths. It is also made into fabrics for household furnishings (upholstery, canvas) and clothing, paper manufacture.

Jute fiber: Building panels, roofing sheets, door frames, door shutters, transport, packaging, geotextiles, and chipboards. ${ }^{[48-50]}$

\section{Conclusion}

Natural fibers have already established as a substitute for synthetic fiber in polymer composites in many applications like automotive, transportation, construction, packaging, etc. Natural fiber offers brighter composite materials rather than synthetic fiber composites whereas both of them own a similar level of mechanical properties. Natural fibers are bio-degradable and they have a lower discharge rate than the synthetic fiber. The physical and mechanical properties of these natural fiber polymer composites can be further improved through the chemical treatment. It's a blessing for us that we are surrounded by various natural resources and fiber but very less of them has been explored and exploited as yet. Fiber reinforced composites are one of the means to utilize natural resources. Further research is still required to extend their application range including improvement of moisture resistance and fire retardance. But, with time these renewable resources and fiber will soon deplete. So, there is a great need to sustain and procure them for future use. We should pursue more productive means to explore the supreme potential and utilize the natural fiber for the progress of science and technology.

\section{References}

[1] Pat AM, González AV and Franco PJH. Effect of Fiber Surface Treatments on the Essential Work Offracture of HDPEContinuous Henequen Fiber-Reinforced Composites. Polymer Testing, 2013, 32(6): 1114-1122. https://doi.org/10.1016/j.polymertesting.2013.06.006

[2] Shinoj S, Visvanathan R, Panigrahi S, et al. Oil Palm Fiber (OPF) and its Composites: A Review. Industrial Crops and Products, 2011, 33(1): 7-22. https://doi.org/10.1016/j.indcrop.2010.09.009

[3] Uddin N. Developments in Fiber-Reinforced Polymer (FRP) Composites for Civil Engineering, in Woodhead Pub- 
lishing Series in Civil and Structural Engineering, Birmingham, Woodhead Publishing, 2013: 558.

https://doi.org/10.1533/9780857098955

[4] Chandramohan D and Marimuthu K. A Review on Natural Fibers. International journal of Research and Reviews in Applied Sciences, 2011, 8(2): 194-206.

[5] Malkapuram R, Kumar V and Negi YS. Recent Development in Natural Fiber Reinforced Polypropylene Composites. Journal of Reinforced Plastics and Composites, 2009, 28(10): 1169-1189. https://doi.org/10.1177/0731684407087759

[6] Taj S, Munawar MA and Khan S. Natural Fiber Reinforced Polymer Composites. Proceesings of Pakistan Acaademy of Sciences, 2007, 44(2): 129-144.

[7] Gunti R and Atluri RP. Study on Effect of Chemical Treatments and Concentration of Jute on Tensile Properties of Long and Continuous Twisted Jute/Polypropylene Composite. Advanced Materials Manufacturing and Characterization, 2013, 3: 395-398. https://doi.org/10.11127/ijammc.2013.02.073

[8] Fuqua MA, Huo S and Ulven CA. Natural Fiber Reinforced Composites. Polymer Reviews, 2012, 52(3): 259-320. https://doi.org/10.1080/15583724.2012.705409

[9] Faruk O, Bledzki AK, Fink PH, et al. Biocomposites Reinforced with Natural Fibers. Progress in Polymer Science, 2012, 37(11): 1552-1596.. https://doi.org/10.1016/j.progpolymsci.2012.04.003

[10] Madhu P, Sanjay MR, Senthamaraikannan P, et al. A Review on Synthesis and Characterization of Commercially Available Natural Fibers: Part-I. Journal of Natural Fiber, 2018: 1-13.

https://doi.org/10.1080/15440478.2018.1453433

[11] Ferreira JM, Silva H, Costa J, et al. Stress Analysis of Lap Joints Involving Natural Fiber Reinforced Interface Layers. Composites Engineering, 2005, 36(1): 1-7. https://doi.org/10.1016/j.compositesb.2004.04.011

[12] Curvelo A, de Carvalho A and Agnelli J. Thermoplastic Starchcellulosic Fibers Composites: Preliminary Results. Carbohydrate Polymers, 2001, 45(2): 183-188. https://doi.org/10.1016/S0144-8617(00)00314-3

[13] Bledzki A, Zhang W and Chate A. Natural Fiber Reinforced Polyurethane Microfoams. Composites Science and Technology, 2001, 61(16): 2405-2411. https://doi.org/10.1016/S0266-3538(01)00129-4

[14] Jayaraman K and Bhattacharya D. Mechanical Performance of Woodfibrewaste Plastic Composite Materials. Resources Conservation and Recycling, 2004, 41(4): 307-319. https://doi.org/10.1016/j.resconrec.2003.12.001

[15] Zulkifli R, Fatt L, Azhari C, et al. Interlaminar Fracture Properties of Fiber Reinforced Natural rubber/Polypropylene Composites. Journal of Materials Processing Technology, 2002, 128(1-3): 33-37. https://doi.org/10.1016/S0924-0136(02)00097-3

[16] Mitra B, Basak R and Sarkar M. Studies on Jute-Reinforced Composites, Its Limitations and Some solutions through Chemical Modifications of Fibers. Journal of Applied Polymer Science, 1998, 67(6): 1093-1100. https://doi.org/10.1002/(SICI)1097-4628(19980207)67: 6<1093::AID-APP17 $>3.0 . C O ; 2-1$
[17] Kandola B, Horrocks A, Myler P, et al. Mechanical Performance of Heat/Fire Damaged Novel Flame Retardant GlassReinforced Epoxy Composites. Composite Part A: Applied Science and Manufucturing, 2003, 34(9): 863-873. https://doi.org/10.1016/S1359-835X(03)00156-8

[18] Eichhorn S and Young RJ. Composite Micromechanics of Hemp Fibres and Epoxy Resin Microdroplets. Composite Science Technology, 2004, 64(5): 767-772. https://doi.org/10.1016/j.compscitech.2003.08.002

[19] Kaith B, Singha A and Susheel K. Mechanical Properties of Raw Flax and Flax-g-poly(MMA) Reinforced PhenolFormaldehyde Composites. International Journal of Plastics Technology, 2006, 10: 572-587.

[20] Singha A, Susheel K and Kaith B. Preparation of Flax-gCopolymer Reinforced Phenol-Formaldehyde Composites and Evaluation of Their Physical and Mechanical Properties. International Journal of Plastics Technology, 2005, 9: 427-437.

[21] Mohammed L, Ansari M, Pua G, et al. A Review on Natural Fiber Reinforced Polymer Composite and Its Applications. International Journal of Polymer Science, 2015: 1-15. https://doi.org/10.1155/2015/243947

[22] Coutinho F and Costa T. Performance of PolypropyleneWood Fiber Composites. Polymer Testing, 1999, 18(8): 581-587. https://doi.org/10.1016/S0142-9418(98)00056-7

[23] Saheb D and Jog J. Natural Fiber Polymer Composites: A Review. Advanced Polymer Technology, 1999, 18(4): 351-363. https://doi.org/10.1002/(SICI)1098-2329(199924)18: 4〈351::AID-ADV6〉3.3.CO;2-O

[24] Maleque M, Belal F and Sapuan S. Mechanical Properties Study of Pseudo-Stem Banana Fiber Reinforced Epoxy Composite. The Arabian Journal for Science and Engineering, 2007, 32(2B): 359-364.

[25] Biswas S, Kindo S and Patnaik A. Effect of Fiber Length on Mechanical Behavior of Coir Fiber Reinforced Epoxy Composites. Fibers and Polymers, 2011, 12(1): 73-78. https://doi.org/10.1007/s12221-011-0073-9

[26] Acharya S, Mishra P and Mehar S. Effect of Surface Treatment on the Mechanical Properties of Bagasse Fiber Reinforced Polymer Composite. BioResources, 2011, 6(3): 3155-3165.

[27] Payae Y and Lopattananon A. Adhesion of Pineappleleaf Fiber to Epoxy Matrix: The Role of Surface Treatments. Journal of Science and Technology, 2009, 31(2): 189-194.

[28] Roe P and Ansell M. Jute-Reinforced Polyester Composites. Journal of Material Science, 1985, 20(11): 4015-4020. https://doi.org/10.1007/BF00552393

[29] Devi L, Bhagawan S and Thomas S. Mechanical Properties of Pineapple Leaf Fiber-Reinforced Polyester Properties. Journal of Applied Polymer Science, 1997, 64(9): 17391748. https://doi.org/10.1002/(SICI)1097-4628(19970531)64 9〈1739::AID-APP10 $\rangle$ 3.3.CO;2-O

[30] Srinivasababu N, Murali M and Suresh K. Tensile Properties Characterization of Okra Woven Fiber Reinforced Polyester Composites. International Journal of Engineering, 2009, 3(4): 403-412. 
[31] Rout J, Misra M, Tripathy S, et al. The Influence of Fiber Surface Modification on the Mechanical Properties of Coir-Polyester Composites. Journal of Polymer Composites, 2001, 22(4): 468-476. https://doi.org/10.1002/pc.10552

[32] Cao Y, Shibata S and Fukumoto I. Mechanical Properties of Biodegradable Composites Reinforced with Bagasse Fibre Before and After Alkali Treatments Composites Part A. Applied Science and Manufacturing, 2006, 37(3): 423-429. https://doi.org/10.1016/j.compositesa.2005.05.045

[33] Thielemans W, Can E, Morye S, et al. Novel Applications of Lignin in Composite Materials. Journal of Applied Polymer Science, 2002, 83(2): 323-331. https://doi.org/10.1002/app.2247

[34] Joseph P, Kuruvilla J and Thomas S. Effect of Processing Variables on the Mechanical Properties of Sisal-Fiber Reinforced Polypropylene Composites. Composites Science and Technology, 1999, 59(11): 1625-1640. https://doi.org/10.1016/S0266-3538(99)00024-X

[35] Kalaprasad G, Joseph K and Thomas S. Theoretical Modeling of Tensile Properties of Short Sisal Fiber Reinforced Low-Density Polyethylene Composites. Journal of Material Polymer Science, 1999, 32(16): 4261-4267.

[36] Bing L, Yuhui H and Guangmin C. Influence of Modified Wood Fibers on the Mechanical Properties of Wood FiberReinforced Polyethylene. Journal of Applied Polymer Science, 1997, 66(8): 1561-1568. https://doi.org/10.1002/(SICI)1097-4628(19971121)66: 8〈1561::AID-APP17 $\rangle$ 3.0.CO;2-6

[37] Facca A, Kortschot M and Yan N. Predicting the Elastic Modulus of Natural Fiber Reinforced Thermoplastics Composite part A. Applied Science and Manufacturing, 2006, 37(10): 1660-1671. https://doi.org/10.1016/j.compositesa.2005.10.006

[38] Okubo K, Fujii $\mathrm{T}$ and Yamamoto Y. Development of Bamboo-Based Polymer Composites and Their Mechanical Properties. Applied Science and Manufacturing, 2004, 35(3): 377-383. https://doi.org/10.1016/j.compositesa.2003.09.017

[39] Hujuri U, Chattopadhay S, Uppaluri R, et al. Effect of Maleic Anhydride Grafted Polypropylene on the Mechanical and Morphological Properties of Chemically Modified Short-Pineapple-Leaf-Fiber-Reinforced Polypropylene Composites. Journal of Apllied Polymer Science, 2008, 107(3): 1507-1516. https://doi.org/10.1002/app.27156

[40] Chattopadhyay S, Khandal R, Uppaluri R, et al. Mechanical, Thermal, and Morphological Properties of Maleic Anhydride-g -Polypropylene Compatibilized and Chemically Modified Banana-Fiber Reinforced Polypropylene
Composites. Journal of Applied Polymer Science, 2010 117(3): 1731-1740. https://doi.org/10.1002/app.32065

[41] Bledzki A, Mamun A, Jaszkiewicz A, et al. Polypropylene Composites with Enzyme Modified Abaca Fiber. Composites Science Technology, 2010, 70(5): 854-860. https://doi.org/10.1016/j.compscitech.2010.02.003

[42] Chattopadhyay S, Khandal R, Uppaluri R, et al. Bamboo Fiber Reinforced Polypropylene Composites and Their Mechanical, Thermal, and Morphological Properties. Journal of Applied Polymer Science, 2011, 119(3): 1619-1626. https://doi.org/10.1002/app.32826

[43] Rana A, Mandal A, Mitra B, et al. Short Jute FiberReinforced Polypropylene Composites: Effect of Compatibilizer. Journal of Applied Polymer Science, 1998, 69(2): 329-338. https://doi.org/10.1002/(SICI)1097-4628(19980711)69: 2〈329::AID-APP14 $>3.0 . C O ; 2-\mathrm{R}$

[44] Tajvidi M, Shekaraby M, Motiee N, et al. Effect of Chemical Reagents on the Mechanical Properties of Natural Fiber Polypropylene Composites. Journal of Polymer Composites, 2006, 27(5): 563-569. https://doi.org/10.1002/pc.20227

[45] Jawaid M and Khalil HA. Cellulosic/Synthetic Fibre Reinforced Polymer Hybrid Composites: A Review. Carbohydrate Polymers, 2011, 86(1): 1-18. https://doi.org/10.1016/j.carbpol.2011.04.043

[46] Hajnalka H, Racz I and Anandjiwala RD. Development of HEMP Fibre Reinforced Polypropylene Composites. Jornal of Thermoplastic Composite Materials, 2008, 21(2): 165174. https://doi.org/10.1177/0892705707083949

[47] Dixit S, Goel R, Dubey A, et al. Natural Fibre Reinforced Polymer Composite Materials - A Review. Polymers from Renewable Resources, 2017, 8(2): 71-78. https://doi.org/10.1177/204124791700800203

[48] Sen T and Reddy H. Various Industrial Applications of Hemp, Kinaf, Flax and Ramie Natural Fibres. International Journal of Innovation, Management and Technology, 2011, 2(3): 192-198.

[49] Bongarde US and Shinde VD. Review on Natural Fiber Reinforcement Polymer Composite. International Journal of Engineering Science and Innovative Technology, 2014, 3(2): 431-436.

[50] Mwaikambo L. Review of the History, Properties and Application of Plant Fibres. African Journal of Science and Technology, 2006, 7(2): 121. 